\title{
How Should the EU Position Itself in a Global Trade War?
}

The last meeting of the European Union's heads of state or government, the European Council of 22-23 March, was dominated by worries about the future of global trade. Since President Donald Trump's announcement to impose tariffs on steel and aluminium imports and the granting of a temporary exemption to the EU, South Korea and number of other countries, the old trade order based on a strong multilateral system has already been undermined de facto if not de jure.

Nothing of President Trump's recent announcements should come as a surprise. In fact, he was elected on an anti-globalisation, anti-China and anti-Germany electoral platform. He also repeatedly questioned the value of a multilateral system throughout his campaign. Contrary to perception, Trump's views on trade follow a longstanding philosophy. In fact, his values reach back at least to a 1990 interview in Playboy, in which he argued that the US should impose tariffs on Mercedes Benz. Trump's words and actions are consistent with a vision.

One of his first actions in office was his declaration that he intended to take the US out of the Paris agreement in preventing climate change. This unilateral action was met by a determined response from the EU and China and led to the isolation of the US in the G20 declaration in Hamburg last year.

But the success of German diplomacy in preserving the international climate agreement may be more difficult to replicate in the trade arena. Isolating the US trade actions and preserving the multilateral system in the face of US resistance may, in fact, turn out to be impossible, and the first cracks in the system are starting to become visible.

After the departure of Gary Cohn, the remainder of Trump's team is now even more firmly made up of individuals who reject multilateralism. Trump's closest trade advisor, $\mathrm{Pe}-$ ter Navarro, and his Commerce Secretary, Wilbur Ross, argue that all deals which lead to a trade deficit for the US should be renegotiated. Meanwhile, Robert Lighthizer, the current United States Trade Representative, has also made his contempt for the WTO known and is a skilful expert on exploiting legal grey zones of the WTO. By purposely justifying the steel and aluminium tariffs as necessary on national security grounds, the US makes it difficult to successfully challenge the tariffs at the WTO, which in principle allows imposition of tariffs for security reasons.

But the challenge presented by the US to the global trading system far exceeds steel and aluminium tariffs. The real question is whether the US can force the EU to join it and become an ally opposing China - if it has not already done so. On the day Trump announced that the EU would be temporarily exempted from the steel and aluminium tariffs, he also decided to impose tariffs on US $\$ 60 \mathrm{bn}$ worth of Chinese imports in response to alleged intellectual property theft and to the US's steep and persistent trade deficit with China.

How should the EU respond? So far, the European Council has declared that it continues to support the multilateral trading system and that it wants the EU to secure more free trade agreements. This follows the successful completion of agreements with Japan and Canada - the timeline for the Japan deal having been accelerated in response to President Trump's election. The European Council has also rightly declared the US tariffs an inappropriate answer to the real problem of steel overcapacity, on which the 
EU has already offered to collaborate with the US to find solutions. The European Council has also announced that it is ready to respond to the US measures with appropriate countermeasures that are in line with the WTO. Finally, it has declared that it values the strategic partnership, including on security matters, with the US.

The EU's response so far has been smart and measured. Yet it also shows that it will be difficult for the EU to maintain a middle course between the US, its primary market and second-largest supplier, and China, its primary supplier and second-largest market. One dimension that must be considered is security. It will be difficult to seriously undermine the transatlantic relationship without significant concerns about Europe's security guarantee.

A second crack in the architecture is that the EU has taken note of the temporary exemptions that the US has granted and would like them to be permanent. As such, that formal declaration has already put a wedge between those countries that have been granted exemptions and China, which has received even more tariffs. In particular, the EU has been treated differently from China at its own request, and that will not have gone unnoticed in Beijing. South Korea has also received exemptions, and Japan is considering how far it can go in resisting Trump. The united front that could be upheld on the climate agreement was not preserved on steel, and Trump skilfully managed to divide the world with these small-scale measures.

Third, political pressure in the EU will likely increase as China and others affected by the US tariffs try to redirect their supplies to the EU, increasing competitive pressures on European firms. Will the EU be able to keep its borders open, or will lobby pressures become so great that the EU will also feel compelled to raise tariffs? This risk may not materialise anytime soon, thanks in part to the positive business cycle and the increasing demand for steel, but the pressure will certainly increase the longer the tariffs last.

Overall, the EU is right to insist on its plan A, which is trying to preserve the global multilateral trading system and bringing both the US and China back to the table in Geneva. Yet Trump's strategy has already begun to crack the global trade architecture, and the EU currently has no plan B.

What the EU needs to do is put a greater focus on its domestic economic policy so as to reduce its dependence on global trade. This strategy will not be easy. But only if we gradually manage to increase domestic investment will our economies become less vulnerable to global trade shocks. And only if we strengthen our security capacities will we become less dependent on the US security umbrella. And only if we strengthen our innovation capacities in systemic digital areas such as cloud computing and $5 \mathrm{G}$ networks will we credibly be able to stand up to US and Chinese dominance in the area.

It is high time for the EU to work on more than wishful thinking on global trade. We should not underestimate the formidable challenge that President Trump poses for our prosperity and security.

Guntram B. Wolff, Bruegel, Brussels, Belgium. 